\title{
Use of medicinal plant in the manufacturing of energetic cookies
}

\author{
Uso de erva medicinal na fabricação de biscoito energético
}

Édira Castello Branco de Andrade GONÇALVES ${ }^{1 \star}$, Roberta Melquiades Silva de ANDRADE ${ }^{1}$

\begin{abstract}
Many nutrients provide energy and regulate physiological processes linked to exercise. This work aimed at using medicinal plant in the manufacturing of energetic cookie. An evaluation of microbiological and physicochemical stability was made within 180 days of the fabrication of the product. Sensorial analysis was performed in all stages with untrained tasters. The results were statistically tested. The evaluation of ergogenic effect of the product used the maximum volume of oxygen index as a parameter through the cooper track test (12 minutes) with 7 voluntaries. The participants received the consent form. This study was approved by the local ethics committee ( $\left.\mathrm{N}^{\circ} \mathrm{CAAE}-0009.0 .313 .000-08\right)$. It was observed good stability for physicochemical and microbiological parameters. As for sensorial analysis there was a predominance of scores 6 to 8, characterizing good acceptance. It was verified increase in VO2 max after the intake of the cookies with or without the medicinal plants. However, the product with the medicinal plants presented a bigger value, $35.47 \mathrm{VO} 2 \mathrm{max} \mathrm{mL} /(\mathrm{kg} . \mathrm{min})^{-1}$. The fraction of carbohydrate and the presence of medicinal plants can be considered as nutritional ergogenic substances. The lipid fraction favor the energetic aspect of the product. The proposed product presented energetic and ergogenic effect.
\end{abstract}

Keywords: medicinal plants; energetic cookie; VO2 max.

\section{Resumo}

Os vários nutrientes alimentares fornecem energia e regulam os processos fisiológicos relacionados ao exercício. O objetivo deste trabalho foi utilizar ervas medicinais na elaboração de biscoito energético. A avaliação da estabilidade físico-química e microbiológica periódica até 180 dias do produto elaborado foi feita, bem como a análise sensorial com provadores não treinados. Os resultados foram tratados estatisticamente. Para avaliação do efeito ergogênico utilizou-se o índice de volume de oxigênio máximo como parâmetro através do teste de pista de Cooper (12 minutos) com 7 voluntários. Os voluntários receberam o termo de esclarecimento e consentimento, aprovado pelo comitê de ética com No CAAE - 0009.0.313.000-08. Observou-se boa estabilidade tanto nos parâmetros físico-químicos quanto no microbiológico. Na análise sensorial, as notas de 6 a 8 foram as mais mencionadas, caracterizando boa aceitação. Foi verificado aumento no VO2 máx tanto no consumo do biscoito energético preparado sem o uso das ervas medicinais quanto no consumo do produto com as ervas medicinais, o qual apresentou maior valor, 35,47 VO2 máx mL/ (kg.min)-1. A fração de carboidratos e a presença das ervas medicinais podem ser consideradas substâncias ergogênicas nutricionais. A fração lipídica favorece o aspecto energético do produto. O produto elaborado apresentou efeito energético e ergogênico.

Palavras-chave: ervas medicinais; biscoito energético; VO2 máx.

\section{Introduction}

The use of medicines made up of plants resembles primitive tribes where women were responsible for extracting active compounds from plants, capable of healing diseases. The first registers of phytomedicines date from the period 2838-2698 b.C. when the Chinese emperor Shen Nung cataloged 365 medicinal plants and poisons. Studies on popular medicine have been drawing increasingly attention owing to increased use of teas and dyes. As a result, the majority of occidental countries have been using medicines made up of plants in a systematic and increasing way to treat or even prevent diseases, besides conventional therapy (ALVES et al., 2000; FRANCA et al., 2008).

Brazil has got the largest biologic diversity worldwide, which includes a rich flora, drawing interest from international scientific communities so as to study, preserve and using rationally these natural resources. Not only does medicinal aspect deserve attention, but also nutritional properties. (SOUZA; FELFILI, 2006).

The use of synthetic antioxidants in food industry has become restrict due to toxic chemical residues associated with carcinogenic and teratogenic actions. Consequently, there is growing interest in the use of plants that retain antioxidant and antimicrobial properties such as rosemary, oregano, thyme, cinnamon, and others (SANTURIO et al., 2007; GENENA et al., 2008; ALMEIDA-DARIO; REGITANO-D'ARCE, 2000).

The majority of nutrients provides energy and regulates physiologic process related to exercise. According to Recommended Daily Intake (RDI), from National Research Council Subcommitee, in 1989, carbohydrates should represent the biggest part of energy intake in a balanced diet (SAPATA; FAYH; OLIVEIRA, 2006).

Received 13/8/2009

Accepted 1/3/2010 (004344)

${ }^{1}$ Departamento de Tecnologia dos Alimentos, Escola de Nutrição, Universidade Federal do Estado do Rio de Janeiro - UNIRIO, Av. Pasteur, 296, $3^{\circ}$ andar, Urca, CEP 22290-240, Rio de Janeiro, RJ, Brasil, e-mail: ediracba@analisedealimentos.com.br

${ }^{*}$ Corresponding author 
Carbohydrates are divided into three main categories: monossacarides, dissacarides and polyssacarides, concerning chemical aspect. Within nutritional classification, carbohydrates are divided according to their digestibility: rapidly digested, where enzymatic action that results in glycosis begin in the mouth and continues until the beginning of small bowel; slowly digested, in which enzymatic action occurs throughout small bowel; and resistant to enzymatic action and therefore to digestion. It's well known that glycogen concentration is directly linked to performance during exercise. Some authors put forward carbohydrate intake pre-exercise as an alternative to minimize glycogen depletion during exercise (SAPATA; FAYH; OLIVEIRA, 2006; FAYH et al., 2007; PARAVIDINO; PORTELLA; SOARES, 2007; LIMA-SILVA et al., 2007; PEREIRA, 2007).

Caffeine is present in countless plants used directly or indirectly as energetic and their use has become commonplace in sports. Ergogenic effect of this substance upon physical performance in aerobic exercises has been demonstrated and lately, caffeine has been excluded from the list of prohibited substances by the World Anti-Doping Agency Anti-Doping (WADA) (ALTIMORI et al., 2006).

All in all, the aim of this study was to use the medicinal plants Paulinea cuppana and Erythroxylum catuaba to manufacture energetic cookies.

\section{Materials and methods}

\subsection{Processing of energetic cookie}

The manufactured product, energetic cookie made up of the medicinal plants Paulinea cuppana e Erythroxylum catuaba is in process of patent.

Energetic cookie was prepared using the following ingredients: Rice flour, green banana flour, orange juice, olive oil, flavor and medicinal plants popular used as energetic. Cookies were elaborated according to 10-50D method, proposed by AACC (AMERICAN ASSOCIATION OF CEREAL CHEMISTS, 1995).

Cookies were packaged in metalized sachets that were sealed and stored in cool and airy place. Product elaboration and physicochemical analysis were performed at Food analysis laboratory, located at Nutrition College in Federal University of the state of Rio de Janeiro from March to September of 2008.

\subsection{Evaluation of physicochemical stability}

Physicochemical stability of the product was evaluated through acidity and peroxide index determinations in the times of $0,15,30,60,90$ and 180 days. In all the times analysis were made four times (ASSOCIATION OF OFFICIAL ANALYTICAL CHEMISTRY, 1997).

The olive oil used as ingredient was subjected to the same protocol to analyze its physicochemical stability.

\subsection{Evaluation of microbiological stability}

Cookies were subjected to microbiological analysis at 0,7 , 15, 60, 90 and 180 days. The parameters used as well as their interpretation were based on $\mathrm{RDC}$ resolution $\mathrm{N}^{\circ} 12,2 / 01 / 2001$ (AGÊNCIA NACIONAL DE VIGILÂNCIA SANITÁRIA, 2001). These analyses were performed at Baktron Laboratory, from March to September of 2008.

\subsection{Sensorial analysis}

Cookies were submitted to sensorial analysis by 120 untrained tasters, distributed in groups of 20 for each time evaluated $(0,15,30,60,90$ and 180 days). Acceptance test considered the attributes of taste and consistency. It was used a hedonic scale of nine points, varying from extremely unlike (grade 1) to extremely liked (grade 9), according to Stone and Sidel (1992). Time 0 was considered when the product was recently elaborated and not packaged to conservation. During all period of analysis of conservation, the product at time 0 was taken as reference.

\subsection{Statistical analysis}

In order to reject discrepant values, the criterion described by Dixon (1953), was used and to make comparisons between the results Student T test was applied (MILLER; MILLER, 2001).

\subsection{Evaluation of ergogenic effect of energetic cookie}

This study is part of the project on development of products based on medicinal plants, peel, seeds and fruit flour aiming at supplementation of fiber, cooper, iron and zinc. The protocol was approved by ethics committee of Federal University of the state of Rio de Janeiro - UNIRIO, being approved with the number CAAE - 0009.0.313.000-08. An evaluation of the ergogenic effect of the product was made, using VO2max as parameter, according to the following protocol.

VO2max was verified through the Cooper track test (12 minutes) with 7 volunteers, being 2 men and 5 women. Volunteers received the consent form, Chart 1, which was properly signed. In order to perform the test, participants were encouraged to run during 12 minutes in a track of $400 \mathrm{~m}$, being that at the final of the circuit, the evaluator measured the total distance traveled by each volunteer. The test of VO2 max was taken three times with intervals of one week at the 'Instituto de Pesquisa da Capacitação Física do Exército' (IPCFEx) located at Urca, Rio de Janeiro, in November and December 2008 (SILVA et al., 2005).

At the first Day of the test, none of the participants consumed the product, being the control Day. At the following days, each participant received a portion of $15 \mathrm{~g}$ of cookie with medicinal plant and without medicinal plant, being considered as placebo. Volunteers did not have information on the kind of cookie offered and the distribution was made at random. Cookie intake happened 30 minutes before the test.

\section{Results and discussion}

Physicochemical stability of the sample varied from $86.81 \mathrm{mg} \mathrm{KOH} \% \pm 0.15$ at day 0 to $96.93 \mathrm{mg} \mathrm{KOH} \% \pm 0.03$ at 180 days. 
There were not significant differences in acidity levels of the samples during all the time of conservation. Food legislation does not establish limits concerning physicochemical stability of cookies. There is reference to cereals, where according to the normative instruction $\mathrm{N}^{\circ} 8$, June 2 nd 2005, the maximum limit of acidity in wheat flour and cereals in general is $100 \mathrm{mg} \mathrm{KOH} \%$ (AGÊNCIA NACIONAL DE VIGILÂNCIA SANITÁRIA, 2005).

Similar product was evaluated concerning centesimal composition by Oliveira, Takase and Gonçalves (2009), as depicted in Table 1.

The major fractions are correspondent to carbohydrates and lipids. Considering the ingredients, described previously, and the water activity of the sample, it can be suggested that the possible deterioration is associated with lipid fraction. Thus, besides considering that hydrolytic degradation of lipids stemmed from flours and olive oil, it was also taken into account oxidative degradation through peroxide index. During all the periods of product conservation, there was not peroxide formation.
The olive oil used as ingredient to product elaboration was also evaluated concerning acidity and peroxide index. The respective results were $0.38 \pm 0.02 \mathrm{~g}$ of oleic acid/ $100 \mathrm{~g}$ of sample. According to the resolution RDC $\mathrm{N}^{\circ} 482$, September 23rd 1999, the maximum limit of acidity index of oleic acid is $1.0 \mathrm{~g} .100 \mathrm{~g}^{-1}$ and for peroxide index the maximum was $20 \mathrm{meg}$ peroxidic oxygen/1000 $\mathrm{g}$ of sample. Then, the olive oil was not deteriorated (AGÊNCIA NACIONAL DE VIGILÂNCIA SANITÁRIA, 1999).

As for microbiological stability (Table 2), it was observed that according to the resolution $\mathrm{RDC}^{\circ} 12,2 / 01 / 2001$ (AGÊNCIA NACIONAL DE VIGILÂNCIA SANITÁRIA, 2001), cookies should present a maximum of 10 Coliforms at $45^{\circ} \mathrm{C} . \mathrm{g}^{-1}$; $5 \times 10^{2}$ coagulase-positive Staphylococci/g; and absence of Salmonella in $25 \mathrm{~g}$ of product. Our product was within these patterns, maintaining microbiological stability during 180 days and therefore the package can be regarded as efficacious for this. The cited resolution does not establish maximum reference values for the others analytic parameters showed.

Chart 1. Consent form to evaluation of ergogenic effect of the energetic cookie.

Me, ÉDIRA CASTELLO BRANCO DE ANDRADE GONÇALVES, nutritionist and pharmaceutics, professor and research of Nutrition College at Federal University of the State of Rio de Janeiro - UNIRIO, whose telephone number is (21) 2542-7418, would like to carry out a research titled as ELABORATION OF PRODUCTS BESED ON FLOUR AND PEELS OF DRUITS AND MEDICINAL PLANTS.

The objective of this study is to manufacture alternative products with functional action. At this moment we are verifying the energetic action of a cookie made up of rice and banana flours with guaraná and catuaba. In this way, we are inviting you to take part in this study, being your participation voluntary and being represented by the intake of the product followed by evaluation of respiratory capacity and anthropometric measurements

You collaboration does not have direct benefit, but Will result in better knowledge concerning nutrional adequacy to the practice of exercises, which in turn other people can benefit from.

I inform that you have guarantee of access at any stage of the study on solving of any doubt. If you have any consideration or doubt upon research's ethics, please contact 'Comitê de Ética em Pesquisa (CEP) of UNIRIO' under the coordination of professor doctor Ricardo Cardoso, Avenida Pasteur 296 - Prédio da Reitoria, telephone number (21) 25427796.

I compromise with the utilization of data collected exclusively to this study and the results will be published in specialized magazines or in scientific meetings and congresses, without allowing your identification.

The consent form bellow should be signed IF you do not have doubts.

Consent form

I believe that I'm sufficiently informed after readind this document, describing the study ELABORATION OF PRODUCTS BESED ON FLOUR AND PEELS OF DRUITS AND MEDICINAL PLANTS. It is clear that my participation will not have any cost and that I have guarantee of access to the results or clarifying any doubts. I agree to take part in this study and can retire my consent at any time, before or during the study, without being penalize or losing any benefit I could have taken.

Volunteer's signature

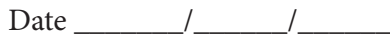

Name:

Address:

Telephone: ( )

Researcher's signature 
Figure 1 shows a histogram of product acceptance, where flavor and consistency were considered. In all times, it was offered to each taster 2 samples that corresponded to the freshly prepared cookie and the cookies at different times of conservation.

It is possible to perceive that there is better acceptance of the product until 90 days of storage, where grade 7 (moderately liked) predominated. Furthermore, grades 1,2 and 3 were not referred during all the study, whereas grades 6 to 8 were the most prevalent, implying a good acceptance of this.

As far as ergogenic effect is concerned, the results of the influence of the energetic cookie upon maximum oxygen volume (VO2 max) can be found in Figure 2.

It can be observed increased VO2 Max after the intake of energetic cookie with or without medicinal plants, when compared to control (without consumption).

The major value, $35.47 \mathrm{VO} 2 \mathrm{max} \mathrm{mL} /(\mathrm{kg} \cdot \mathrm{min})^{-1}$, was reached after the use of energetic cookie made up of medicinal plants.

Ergogenic resources are characterized by substances used as a tentative of enhancing physical potential, mental strength and mechanical efficacy. These can be classified as biomechanical, psychological and nutritional (ALTIMARI et al., 2006; MELLO; KUNZLER; FARAH, 2007).

Caffeine is a substance that does not present nutritional value, being classified as a pharmacologically active alkaloid, stimulating central nervous system (CNS). However, this substance has been considered a nutritional ergogenic, which acts increasing exercise lipolysis, sparing glycogen utilization, which in turn enhances contraction strength and decreases fatigue (ALTIMARI et al., 2000, 2006; MELLO; KUNZLER; FARAH, 2007).

Table 1. Centesimal composition of energetic cookie made up of medicinal plants (OLIVEIRA; TAKASE; GONÇALVES, 2009).

\begin{tabular}{lc}
\hline Fractions $\left(\mathrm{g} .100 \mathrm{~g}^{-1}\right)$ & Energetic cookie \\
\hline Moisture & $2.65 \pm 0.09$ \\
Mineral content & $6.48 \pm 0.14$ \\
Carbohydrate & $68.01 \pm 0.35$ \\
Protein & $5.4 \pm 0.18$ \\
Lipid & $14.43 \pm 0.87$ \\
Fiber & $3.03 \pm 0.33$ \\
\hline
\end{tabular}

Table 2. Microbiological profile of energetic cookie packaged in metallic sachets and conserved until 180 days $^{\star}$.

\begin{tabular}{ll}
\hline \multicolumn{1}{c}{ Analytic parameter } & Energetic cookie \\
\hline Presence of Salmonella spp & Absence. $25 \mathrm{~g} \mathrm{~g}^{-1}$ \\
Counting of Coliforms at $35{ }^{\circ} \mathrm{C}$ & $<0.3$ coliforms.g ${ }^{-1}$ \\
Counting of Coliforms at $45^{\circ} \mathrm{C}$ & $<0.3$ coliforms.g ${ }^{-1}$ \\
Counting of Escherichia coli & $<0.3$ E.coli.g ${ }^{-1}$ \\
Counting of coagulase positive Staphylococcus & $<3$ staphyl.g ${ }^{-1}$ \\
Counting of Molds and yeasts & $<10 \mathrm{CFU.g}{ }^{-1}$ \\
Counting of Bacillus ceruse & $<10 \mathrm{CFU.g}{ }^{-1}$ \\
Counting of bacteria & $80 \mathrm{CFU} \cdot \mathrm{g}^{-1}$ \\
\hline
\end{tabular}

${ }^{*}$ Microbiological parameters were analyzed at times $0,7,15,60,90$ and 180 days and the results found were equal during all the period of conservation.
The ergogenic property of caffeine upon physical performance during aerobic exercises has been demonstrated after the intake of acute doses of this substance ( 3 to $6 \mathrm{mg} \cdot \mathrm{kg}^{-1}$ body mass) (ALTIMARI et al., 2006).

Our product presented $31,4 \mathrm{mg} .100 \mathrm{~g} \mathrm{~g}^{-1}$. Similar levels of caffeine were found by Oliveira, Takase and Gonçalves (2009), in a study where a method for extraction and quantification of caffeine in lipidic samples was developed.

It was observed that caffeine, related to medicinal plants present in the energetic cookie, had ergogenic effect after the intake of a portion of $15 \mathrm{~g}$, corresponding to $5 \mathrm{mg}$ of the compound.

Carbohydrates can be considered as a nutritional ergogenic resource provided that it acts in the maintenance of blood glucose and it may well enhance anaerobic physical performance (SULAMI-GARCIA et al., 2004).

The manufactured product presents a high content of carbohydrate, which characterize it as energetic.

There is also the energetic effect stemmed from lipids, second major fraction of the product. This fraction is basically correlated with olive oil. This fact adds functional aspect to the

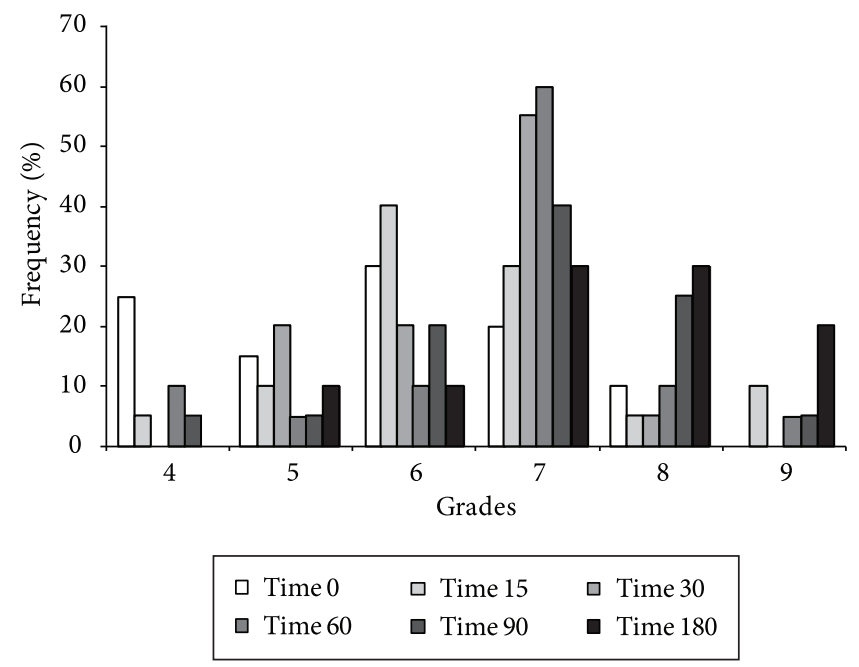

Figure 1. Frequency of grades obtained in the acceptance test $\mathrm{f}$ the energetic cookie conserved until 180 days.

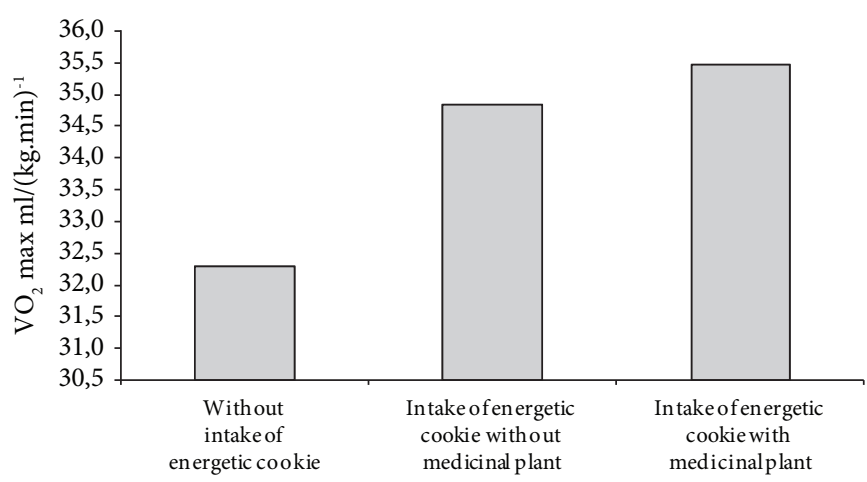

Figure 2. Average value of $\mathrm{VO} 2$ max obtained after the cooper track test (12 minutes) with and without consumption of energetic cookie. 
product considering the nutritional quality of this lipid source. According to Angelis (2001), the protective effects related to the content of monounsaturated fatty acid, especially to bioactive compounds like polyphenols, which act as potent inhibitor of free radicals, LDL-cholesterol oxidation, platelet aggregation and antithrombotic.

\section{Conclusions}

The product, energetic cookie elaborated with and without medicinal plants produced better performance during physical activity, which might be linked to ergogenic nutritional effects related to lipid and carbohydrate fractions as well as energetic properties of medicinal plants used.

\section{Acknowledgements}

The authors would like to thank BAKTRON MICROBIOLOGIA, in especially Dr Renato Geraldo da Silva Filho for support and attention and the 'Instituto de Pesquisa da Capacitação Física do Exército' (IPCFEx), especially captain Adriano Pereira and the professor doctor Marcos Fortes.

\section{References}

AGÊNCIA NACIONAL DE VIGILÂNCIA SANITÁRIA (Brasil). Resolução - RDC n 482, de 23 de Setembro de 1999. Regulamento Técnico para Fixação de Identidade e Qualidade de óleos e gorduras vegetais. Diário Oficial da República Federativa do Brasil, Brasília, DF, 11 mar.1999.

AGÊNCIA NACIONAL DE VIGILÂNCIA SANITÁRIA (Brasil). Resolução - RDC no 12, de 2 de janeiro de 2001. Regulamento Técnico sobre os padrões microbiológicos para alimentos. Diário Oficial da República Federativa do Brasil, Brasília, DF, 10 jan. 2001.

AGÊNCIA NACIONAL DE VIGILÂNCIA SANITÁRIA (Brasil). Instrução Normativa $n^{\circ} 8$, de 02 de Junho de 2005. Regulamento Técnico de Identidade e Qualidade da Farinha de Trigo. Diário Oficial da República Federativa do Brasil, Brasília, DF, 3 jun. 2005. Seção 1, p. 91.

ALVES, T. M. et al. Biological screening of Brazilian medicinal plants. Mem Inst Oswaldo Cruz, v. 95, n. 3, p. 367-73, 2000. http://dx.doi. org/10.1590/S0074-02762000000300012

ALMEIDA-DORIA, R. F.; REGITANO-D'ARCE, M. A. B. Antioxidant activity of rosemary and oregano ethanol extracts in soybean oil under thermal oxidation. Ciência e Tecnolologia dos Alimentos, v. 20, n. 2, p. 197-203, 2000.

ALTIMARI, L. R. et al. Efeitos ergogênicos da cafeína sobre o desempenho físico. Revista Paulista de Educação Física, v. 14, n. 2, p. 141-158, 2000.

ALTIMARI, L. R. et al. Cafeína e exercício físico aeróbio. Nutrire: Revista da Sociedade Brasileira de Alimentação e Nutrição, v. 31, n. 1, p. 79-96, 2006.

AMERICAN ASSOCIATION OF CEREAL CHEMISTS. Approved Methods of the American Associatioon of Cereal Chemists. 9th ed. Saint Paul: AACC, 1995.

ANGELIS, R. C. Novos conceitos em nutrição. Reflexões a respeito do elo dieta e saúde. Arquivo de gastroenterologia, v. 38 , n. 4, p. 269-271, 2001.

ASSOCIATION OF OFFICIAL ANALYTICAL CHEMISTRY. Official Methods of Analysis of the Association og Official Analytical Chemistry. 16th ed. Gaitherburg: AOAC, 1997.
FAYH, A. P. T. et al. Efeitos da ingestão prévia de carboidrato de alto índice glicêmico sobre a resposta glicêmica e desempenho durante um treino de força. Revista Brasileira de Medicina de Esporte, v. 13, n. 6, p. 416-420, 2007.

FRANCA, I. S. X. et al. Medicina popular: benefícios e malefícios das plantas medicinais. Revista Brasileira de Enfermagem, v. 61 , n. 2, p. 201-208, 2008. http://dx.doi.org/10.1590/S003471672008000200009

GENENA, et al. Rosemary (Rosmarinus officinalis): a study of the composition, antioxidant and antimicrobial activities of extracts obtained with supercritical carbon dioxide. Ciência e Tecnologia dos Alimentos, v. 28, n. 2, p. 463-469, 2008.

LIMA-SILVA, A. E. et al. Metabolismo do glicogênio muscular durante o exercício físico: mecanismos de regulação. Revista de Nutrição, v. 20 , n. 4 , p. 417-429, 2007. http://dx.doi.org/10.1590/S141552732007000400009

MELLO, D.; KUNZLER, D. K.; FARAH, M. A cafeína e seu efeito ergogênico. Revista Brasileira de Nutrição Esportiva, v. 1, n. 2, p. 30-37, 2007.

MILLER, J; MILLER, J. Statistics and Chemometrics for Analytical Chemistry. 4th ed. Inglaterra: Prentice Hall, 2001.

OLIVEIRA, K. E.; TAKASE, I.; GONÇALVES, E. C. B. A. development of gluten-free cookie from medicinal plants (Guaraná -Paullinea cupana and Catuaba - Anemopaegma mirandum) aiming at copper, iron and zinc supplementation. Ciência e Tecnologia de Alimentos, v. 29, n. 3, p. 631-635, 2009

OLIVEIRA, J. V. F. et al. A fast method of caffeine extraction from fatty matrices for its determination by HPLC-UV-DAD. Food Chemistry, 2009.

PARAVIDINO, A. 1. B.; PORTELLA, E. S.; SOARES, E. A. Metabolismo energético em atletas de endurance é diferente entre os sexos. Revista de Nutrição, v. 20, n. 3, p. 317-325, 2007. http://dx.doi. org/10.1590/S1415-52732007000300010

PEREIRA, K. D. Amido resistente, a última geração no controle de energia e digestão saudável. Ciência e Tecnologia dos Alimentos, v. 27, n. 1, p. 88-92, 2007.

SANTURIO, J. M. et al. Atividade antimicrobiana dos óleos essenciais de orégano, tomilho e canela frente a sorovares de Salmonella enterica de origem avícola. Ciência Rural, v. 37, n. 3, p. 803-808, 2007. http://dx.doi.org/10.1590/S0103-84782007000300031

SAPATA, K. B.; FAYH, A. P. T.; OLIVEIRA, A. R. Efeitos do consumo prévio de carboidratos sobre a resposta glicêmica e desempenho. Revista Brasileira de Medicina do Esporte, v. 12, n. 4, p. 189-194, 2006. http://dx.doi.org/10.1590/S1517-86922006000400005

SILVA, A. S. R. et al. Comparação entre métodos invasivos e não invasivo de determinação da capacidade aeróbia em futebolistas profissionais. Revista Brasileira de Medicina do Esporte, v. 11, n. 4, p. 233-237, 2005.

SOUZA, C. D.; FELFILI, J. M. Uso de plantas medicinais na região de Alto Paraíso de Goiás, GO, Brasil. Acta Botanica. Brasilica, v. 20 , n. 1 , p. $135-142,2006$. http://dx.doi.org/10.1590/S010233062006000100013

STONE, H.; SIDEL, J. L. Sensory evaluation practices. 2th ed. San Diego: Academic Press, 1992.

SULAMI-GARCIA, E. et al. Efeitos de carboidratos e eletrólitos sobre a termorregulação e a potencia anaeróbia medida após um exercício prolongado no calor. Revista Brasileira de Educação Física e Esporte, v. 18, n. 2, p. 179-189, 2004. 